\title{
Paraconcinnum leirsi n.sp. (Trematoda: Dicrocoeliidae) from rodents in Tanzania and its phylogenetic position within the dicrocoeliids
}

\author{
A. Ribas ${ }^{1 *}$, R.H. Makundi² \& J. Goüy de Bellocq ${ }^{1,3}$ \\ ${ }^{1}$ Evolutionary Ecology Group, University of Antwerp, Groenenborgerlaan 171, B-2020 Antwerpen, Belgium \\ ${ }^{2}$ Pest Management Centre, Sokoine University of Agriculture, P.O. Box 3110, Morogoro, Tanzania \\ ${ }^{3}$ Institute of Vertebrate Biology, Academy of Sciences of the Czech Republic, 60563 Brno, Czech Republic
}

Received 27 January 2012. Accepted 19 November 2012

\begin{abstract}
The trematode Paraconcinnum leirsi n.sp. (Dicrocoeliidae) is described from two rodent species, the African gerbil, Gerbilliscus vicinus, and the spiny mouse, Acomys spinosissimus, from Tanzania. It differs from the description of $P$. hylomisci found in the Stella wood mouse, Hylomyscus stella, in the Democratic Republic of Congo. Molecular studies were performed by sequencing the near complete 18S rDNA gene of the fluke to assess its phylogenetic position within the Dicrocoeliidae. The resulting estimate of evolutionary divergence between the fluke and other dicrocoeliids was $1.60 \pm 0.22 \%$ base differences per site. The phylogenetic analysis shows that the fluke is a new species within Dicrocoeliidae falling in a cluster with the genera Corrigia, Lyperosomum, Concinnum and Eurytrema although phylogenetic relationships among these genera are not well resolved. This is the first dicrocoeliid reported from rodents in eastern Africa.
\end{abstract}

Key words: Acomys, Dicrocoeliidae, Gerbilliscus, Paraconcinnum, 18S rDNA gene.

\section{INTRODUCTION}

The family Dicrocoeliidae Loos, 1899 comprises over 400 species. It is one of few digenean trematode families that complete their life cycles in the terrestrial environment, usually via a snail and an arthropod as first and second intermediate hosts respectively (Pojmaśka 2008). These trematodes are mainly found in the bile ducts and gall bladders of birds and placental mammals and more rarely in reptiles and marsupials (Pojmaśka 2008).

The helminth parasites of African rodents are poorly known and have only been investigated in a fragmentary way across the continent. The genus Paraconcinnum Vassiliadès \& Richard, 1970 (family Dicrocoeliidae) is represented by P. hylomisci Vassiliadès \& Richard, 1970, and found in the murid Hylomyscus stella (Thomas, 1911) from the Democratic Republic of Congo and later reported by Quentin (1989) in Central African Republic. The literature review of helminths of African mammals (from 1800 to 1967) by Canaris \& Gardner (2003) does not include dicrocoeliids of rodents. Yet, to date Lyperosomum africanum Baer, 1957 in Lophuromys sikapusi (Temminck, 1853) and Malacomys longipes edwardsi (Milne-Edwards,

*Author for correspondence. E-mail: alexisribas@hotmail.com
1877); Dicrocoelium ivoriensi Baer, 1971 in Praomys tullbergi (Thomas, 1894); Hemixenotrema hunkeleri Baer, 1971 in Praomys tullbergi and Hybomys trivirgatus (Temminck, 1853) and Euparadistomum lophuromidis Baer, 1971 from Lophuromys sikapusi, all reported from the Ivory Coast by Baer (1957, 1971) from the family Dicrocoeliidae have been described in African rodents.

In Tanzania, studies of helminths of rodents (excuding dicrocoeliids) are limited to those of the Gambian pouched rat, Cricetomys gambianus Waterhouse, 1840 (Khalil 1973; Gibbons et al. 1990) despite the fact that 110 rodent species are found in Tanzania (Senzota et al. 2012). A study of helminths of rodents by Oguge et al. (1997) in central Kenya reported no dicrocoeliids in any of the studied rodents (Mastomys natalensis Smith, 1834 ( $n=14)$; Lemniscomys striatus (Linnaeus, 1758) $(n=7)$; Arvicanthis niloticus (Geoffrey, 1803) $(n=6)$; Mus minutoides (Smith, 1834) $(n=1)$, and Gerbilliscus robustus (Cretzschmar, 1826) $(n=1))$.

In order to gain insight into the diversity and composition of the helminth community in rodents, we carried out a study in the Morogoro region. A trematode belonging to the genus Paraconcinnum Vassiliadès \& Richard, 1970 was recovered and showed morphological and metrical characteristics 
that pointed to a new species. Alongside the morphological and metrical classification we performed a molecular study using the $18 \mathrm{~S}$ rDNA gene which placed this new species within the Dicrocoeliidae.

\section{MATERIALS \& METHODS}

\section{Field work}

Field sampling took place in mid-December 2009. The study area was located in Maguha in the north of the Morogoro Region, Tanzania $\left(\mathrm{S}^{\circ} 17.187^{\prime}, \mathrm{E} 37^{\circ} 11.890^{\prime}\right)$. In total, eight grids of 1 ha were set in fallow lands with 100 Sherman traps each. Dissections were performed in a field laboratory to recover fresh material for optimal fixation of the digeneans. The four sampled rodent species were the spiny mouse, Acomys spinosissimus Peters, $1852(n=4)$, the red rock rat, Aethomys chrysophilus (De Winton, 1897) $(n=2)$, the multimammate mouse, Mastomys natalensis $(n=11)$ and the African gerbil, Gerbilliscus vicinus (Peters, 1878) $(n=11)$. The field identification (based on external but not cranial measurements) of the rodent species was later confirmed by sequencing the cytochrome $\mathrm{b}$ gene using L7 and $\mathrm{H} 6$ primers (Montgelard et al. 2002).

\section{Morphological analysis}

Trematodes were isolated from pancreatic ducts and a portion was preserved in $70 \%$ ethanol for molecular studies and the remainder were fixed in Bouin's solution for morphological studies. The latter were dehydrated through a series of graded ethanols, cleared with xylene and mounted in Canada balsam directly or after staining in Semichon acetocarmine. Measurements of the holotype and eight paratypes were taken using a microscopemounted camera. Illustrations were drawn with the aid of a camera lucida (Figs 1a \& 2).

\section{Molecular analysis}

Total DNA was extracted from a single worm using the DNeasy tissue kit (Qiagen) and eluted in $50 \mu \mathrm{l}$ of AE buffer. Since the number of available sequences from the Dicrocoeliidae is limited in public databases, we also extracted DNA from a specimen of Corrigia vitta (Dujardin, 1845) previously isolated from the rodent Apodemus sp. from Montseny Natural Park (Spain). Polymerase chain reaction (PCR) amplification was performed in $25 \mu \mathrm{l}$ volume containing $0.2 \mu \mathrm{M}$ of each primer, $0.2 \mathrm{mM}$ of each dNTP, $2.5 \mathrm{mM} \mathrm{MgCl}_{2}, 1 \mathrm{X}$ DreamTaq buffer, 0.6 unit of DreamTaq DNA Poly- merase (Fermentas) and $3 \mu \mathrm{l}$ of DNA template. Thermal cycling profile was as follows: an initial denaturing step at $94^{\circ} \mathrm{C}$ for $3 \mathrm{~min}$, followed by 40 cycles at $94^{\circ} \mathrm{C}$ for $30 \mathrm{~s}, 54^{\circ} \mathrm{C}$ for $30 \mathrm{~s}$ and $72^{\circ} \mathrm{C}$ for 2 min and ending with an extension step of $72^{\circ} \mathrm{C}$ for $10 \mathrm{~min}$. Near-complete $18 \mathrm{~S}$ rDNA sequences ( $1800 \mathrm{bp})$ were amplified using primers Worm-A and Worm-B (Littlewood \& Olson, 2001). PCR products were visualized on a $1.4 \%$ agarose gel, and were purified and sequenced by VIB Genetic Service Facility (University of Antwerp, Belgium) using the same primers that generated the PCR products together with two internal primers: 1270R and 930F (Littlewood \& Olson, 2001). The two new partial $18 \mathrm{~S}$ rDNA sequences have been deposited in GenBank (AN: JN831598 and JN831599).

Sequences were aligned using Clustal W (Thompson et al. 1994) together with all Dicrocoeliidae $18 \mathrm{~S}$ rDNA available in GenBank: Concinnum ten (Yamaguchi, 1939) (AB521801), Brachylecithum lobatum (Railliet, 1900) (AY222144), Lyperosomum collurionis (Skrjabin \& Issatschikov, 1927) (AY222143), Dicrocoelium chinensis (Sudarikov and Ryjikov, 1951) Tang \& Tang, 1978 (syn: Dicrocoelium orientalis (Sudarikov and Ryjikov, 1951) and Dicrocoelium suppereri (Sudarikov and Ryjikov, 1951) Hinaidy, 1983) (EF547131), D. dendriticum (Rudolphi, 1819) (Y11236), Eurytrema coelmaticum (Giard \& Billet, 1892) (DQ401035) and E. pancreaticum (Janson, 1889) (DQ401034). Encyclometra colubrimurorum (Rudolphi, 1819) Dollfus, 1929 (Encyclometridae; AY222142) and Orchipedum tracheicola Braun, 1901 (Orchipedidae; AJ287551) were used as outgroups. The final alignments included 1769 nucleotides. Distances were computed using the p-distance method in MEGA 5.05 (Tamura et al. 2011). jModelTest 0.1.1 (Posada 2008; Guindon \& Gascuel 2003) was used to evaluate the fit of 88 nested models of nucleotide substitution to the data using the Akaike Information Criterion (AIC). The AIC indicated that the model best fitting the data is the general time-reversible model with a proportion of invariables sites $(G T R+I)$. Phylogenetic reconstruction was performed by Maximum Likelihood (ML) with the PhyML online web server (Guindon et al. 2005). Branch supports were evaluated by a non-parametric bootstrap analysis (1000 replicates) and an approximate likelihood-ratio test (aLRT) relying on a non-parametric Shimodaira-Hasegawa (SH)-like procedure (Guindon et al. 2010). 

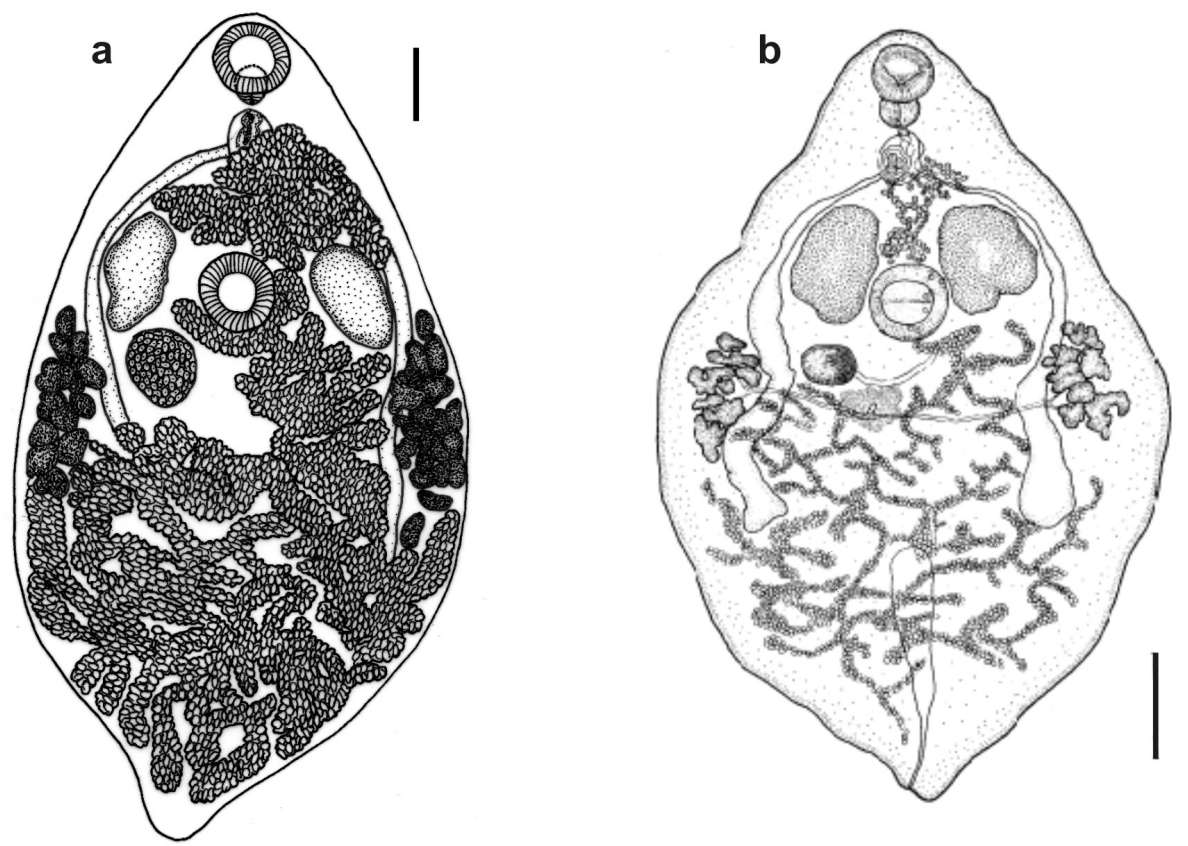

Fig 1. a, Paraconcinnum leirsin.sp. Holotype, ventral view of whole individual. Scale bar $=400 \mu \mathrm{m}$. b, Paraconcinnum hylomisci (from the original description of Vassiliadès \& Richard (1970). Scale bar $=500 \mu \mathrm{m}$.

\section{RESULTS \& DISCUSSION}

\section{Paraconcinnum leirsi n.sp., Fig. 1a \& 2}

\section{Description $(\mathrm{n}=9)$}

Dicrocoeliidae, with characteristics of genus Paraconcinnum according to Pojmaśka (2008). Body elongate, lancet-shaped, $4086 \mu \mathrm{m}(3220-4829 \mu \mathrm{m})$ long, tegument not spined. Body width at level of the acetabulum $1949 \mu \mathrm{m}(1548-2281 \mu \mathrm{m})$; widest at vitellaria level $2302 \mu \mathrm{m}$ (1786-2908 $\mu \mathrm{m})$. Anterior and posterior ends bluntly pointed. Oral sucker subterminal; $363 \mu \mathrm{m}$ (294-431 $\mu \mathrm{m})$ long; $440 \mu \mathrm{m}$ (392-484 $\mu \mathrm{m})$ wide. Acetabulum closer to anterior extremity than to equator, $436 \mu \mathrm{m}(394-458 \mu \mathrm{m})$ long; $437 \mu \mathrm{m}(363-503 \mu \mathrm{m})$ wide. Distance anterior end to beginning ventral sucker $1215 \mu \mathrm{m}$ (1024$1473 \mu \mathrm{m}$ ). Sucker ratio (maximum diameter oral sucker-ventral sucker $0.99(0.77-1.16 \mu \mathrm{m})$. Pharynx $182 \mu \mathrm{m}(158-218 \mu \mathrm{m})$ long; $212 \mu \mathrm{m}$ (184-263 $\mu \mathrm{m})$ wide. Oesophagus totally covered by cirrus sac. Caeca descending by the internal border of vitellogen glands, extending to the second third of body. Genital pore opening immediately posterior to oral sucker. Testes longer than wide, elliptical, with irregular contour, intracaecal, at level of centre of acetabulum, right testis: $604 \mu \mathrm{m}$ (324-899 $\mu \mathrm{m})$ long; $348 \mu \mathrm{m}(200-517 \mu \mathrm{m})$ wide; left testis: $522 \mu \mathrm{m}$ (324-908 $\mu \mathrm{m})$ long; $419 \mu \mathrm{m}$ (224-704 $\mu \mathrm{m})$ wide. Cirrus sac elongate, $295 \mu \mathrm{m}$ (236-382 $\mu \mathrm{m})$ long; $165 \mu \mathrm{m}$ (114-287 $\mu \mathrm{m})$ wide. Orientation of cirrus sac variable, from parallel to perpendicular with respect to the body. Ovary oval, $378 \mu \mathrm{m}(258-472 \mu \mathrm{m})$ long; $338 \mu \mathrm{m}$ (263-413 $\mu \mathrm{m})$ wide, closer to right testis. Uterus

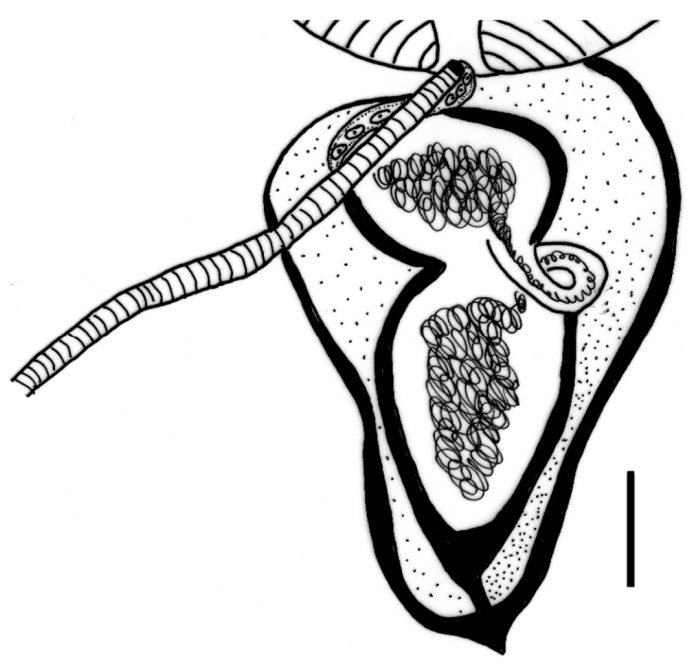

Fig. 2. Paraconcinnum leirsin.sp. Cirrus sac. Scale bar = $50 \mu \mathrm{m}$. 
descending to posterior part of body and then ascending occupying intra-testicular space, once past testis occupies anterior part of body to genital pore. Vitellaria begin at level of distal half of testes; completely extra-caecal; right vitelline gland $966 \mu \mathrm{m}(703-1196 \mu \mathrm{m})$ long; maximum width $357 \mu \mathrm{m}(212-443 \mu \mathrm{m})$; distance from right follicles to end of body $1626 \mu \mathrm{m}(1112-2300 \mu \mathrm{m})$; distance from right follicles to beginning of body on the right $1611 \mu \mathrm{m}(1376-1835 \mu \mathrm{m})$; number right follicles (25-11). Left vitelline gland $1144 \mu \mathrm{m}$ (903-1463 $\mu \mathrm{m}$ ) in length; maximum width $366 \mu \mathrm{m}$ (265-484 $\mu \mathrm{m})$; distance from left follicles to end of body $1758 \mu \mathrm{m}$ (1351-2141 $\mu \mathrm{m})$; distance from left follicles to beginning of body $1462.44 \mu \mathrm{m}$ (1142-1780 $\mu \mathrm{m})$; number left follicles (11-29). Excretory vesicle Y-shaped, excretory pore terminal. Eggs elliptical, operculate, brown in colour, $50 \mu \mathrm{m}(46-54 \mu \mathrm{m})$ long by $26 \mu \mathrm{m}(21-29 \mu \mathrm{m})$ wide.

\section{Taxonomic summary}

Type host

Gerbilliscus vicinus (Peters, 1878).

Other host

Acomys spinosissimus Peters, 1852.

Site of predilection

Pancreatic ducts, the dissection of biliary ducts allowed recovery of this worm, folded longitudinally.

\section{Type locality}

Maguha, Morogoro Region, eastern-central Tanzania, (S6 $\left.{ }^{\circ} 17.187^{\prime} ; \mathrm{E}^{\circ} 7^{\circ} 11.890^{\prime}\right)$.

\section{Type specimens}

Type specimens were deposited in 'Museu de Ciències Naturals de Barcelona' (Barcelona Natural Science Museum, Catalonia, Spain), codes of holotype MZB 2011-0009, and eight paratypes MZB 2011-0010-0017.

\section{Collection date}

December 2009.

\section{Prevalence, intensity of infection and range}

Gerbilliscus vicinus 45.5\%; 3.2, 2-4; Acomys spinosissimus $25 \%$; 2, 2-2.

\section{Etymology}

This species is named in honour of Professor Herwig Leirs for his valuable contribution to the understanding of the ecology and biology of small African mammals.

\section{Remarks}

Paraconcinnum leirsi n.sp. differs from P. hylomisci, the single known species of this genus described by Vassiliadès \& Richard (1970) using morphology and metrical characters. In P. leirsi n. sp. the testes extend posteriorly to the level of the ventral sucker, unlike in P. hylomisci (Fig. 1b) where they never reach posterior margin of ventral sucker. In $P$. hylomisci, the uterine fields only reach the central region of the anterior part of the body, whilst in P. leirsi they cover all the anterior part. Paraconcinnum leirsi $n$.sp. shows a higher number of vitelline follicles (10-29 compared with 8-10 $\mu \mathrm{m}$ in P. hylomisci). Ratio length/width of vitellogen glands 3:1, being 1:1 in P. hylomisci (according to the drawing as measurements of vitelline glands are missing in the description of P. hylomisci). Oral sucker longer and wider in P. leirsi n.sp. (294-431 $\mu \mathrm{m}$ and 392-484 $\mu \mathrm{m}$, respectively) than in P. hylomisci (250-300 $\mu \mathrm{m}$ and $300-350 \mu \mathrm{m}$, respectively).

\section{Phylogenetic relationship}

The $18 \mathrm{~S}$ based estimate of evolutionary divergence between Paraconcinnum leirsi n. sp. and other dicrocoeliids is $1.60 \pm 0.22 \%$ (range: $1.14 \pm$ $0.27 \%-2.05 \pm 0.31 \%$ ) base differences per site. The phylogenetic analysis places the new species within the dicrocoeliids, consistent with the morphological and metrical analysis. The ML tree is shown in Fig. 3. Two major clades were resolved within the dicrocoeliids: the first clade groups Brachylecithum lobatum with Dicrocoelium spp. The second clade, in which both members sequenced herein (Paraconcinnum leirsi n.sp. and Corrigia vitta) belong, is not fully resolved: a cluster grouping Concinnum ten with Eurytrema spp. is highly supported, but the remaining members form a polytomy. The limited number of available sequences of the $18 \mathrm{~S}$ rDNA gene, which is the gene the most represented for the dicrocoeliid family in current public databases, limits further interpretation.

\section{Concluding remarks}

Our knowledge of Dicrocoeliidae in Rodentia is far from complete, as indicated by numerous recent descriptions, e.g. in Europe (Hildebrand et al. 2007); North America (Lamothe-Argumedo et al. 2005) and South America (Gardner \& Pérez-Ponce de Léon 2002; Rivillas et al. 2004). In his review of the family Dicrocoeliidae, Pojmanśka (2008) found that the great variability of body-shape, size and topography of the internal organs makes it diffi- 


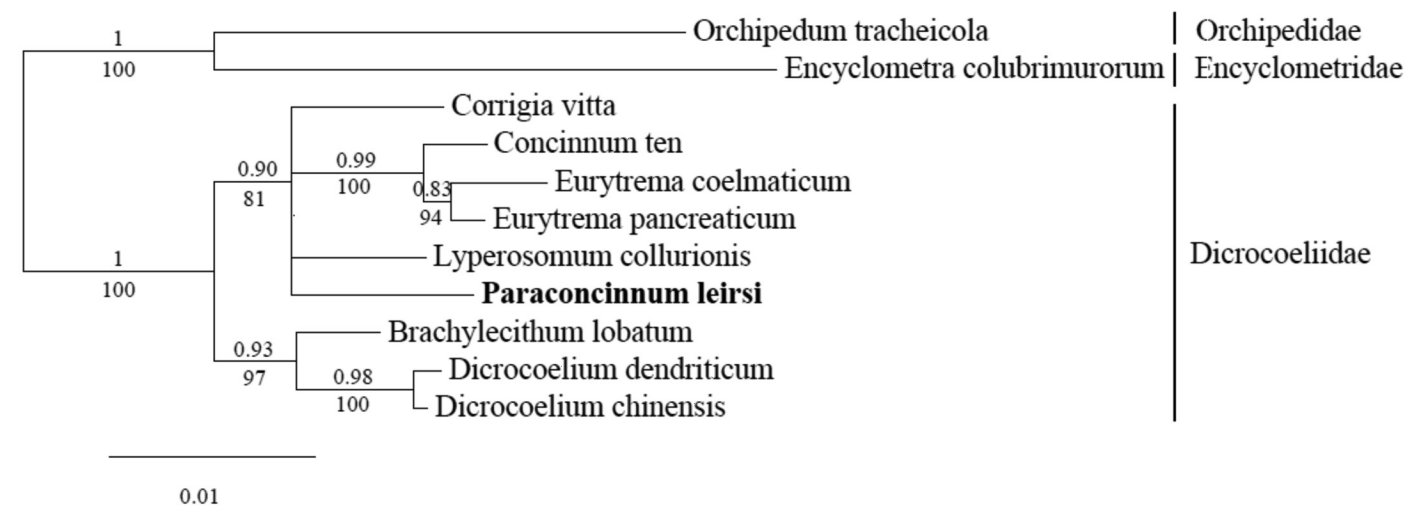

Fig. 3. Phylogenetic analyses of dicrocoeliidae trematodes based on the 18S rDNA showing the position of Paraconcinnum leirsi n.sp. The new species is shown in bold. Numbers on the branches represent the aLRT SH-like support and below the branch percentage bootstrap support (1000 replicates). Encylometra colubrimurorum and Orchipedum tracheicola were used as outgroups. All sequences are taken from GenBank except Paraconcinnum leirsi n.sp. and Corrigia vitta sequenced for this study. Scale bar indicates number of substitutions per site. Branches with an aLRT support $\leq 0.75$ or with a bootstrap support $<50 \%$ were collapsed.

cult to arrange this family into a clear system from higher taxa to the genus level, which has led different authors to propose several taxonomic arrangements. Molecular analyses, as in the present study, or with additional markers, would likely clarify the phylogenetic positions of the dicrocoeliid genera. Paraconcinnum leirsi n. sp. is the second species to have been described in this genus and the first rodent-borne dicrocoeliid described from Africa in 40 years. The first Paraconcinnum species, P. hylomisci, was reported from a rodent species, $H$. stella, that inhabits rainforest habitats (Schlitter \& Van Der Straeten 2008). In contrast, the new species, P. leirsi was found in two rodent species characteristic of more open and dry habitats such as miombo woodlands and grasslands (Verheyen et al. 2011). This habitat difference may have played a role in the speciation of the genus Paraconcinnum. Additional trematode surveys of rodents across these different habitats may clarify the relative influence of habitats and hosts (intermediate and final) in Paraconcinnum speciation.

\section{ACKNOWLEDGEMENTS}

Fieldwork was performed with the help of S. Gryseels and S.J.E. Baird and the enthusiastic staff at Sokoine University of Agriculture Pest Management Centre, in particular K. Kibwana and S. Lutea. We thank S. Gryseels for the sequencing of $M$. natalensis and A. spinosissimus and V. Mazoch for the sequencing of $A$. chrysophilus. The field work was in part funded by the Fund for
Scientific Research-Flanders (FWO) (J.G.B. grant No. 1.5.180.09). J.G.B. and A.R. are postdoctoral and visiting postdoctoral fellows with FWO.

\section{REFERENCES}

BAER, J.G. 1957. Trématodes et Cestodes récoltés en Côte d'Ivoire, avec remarques sur la famille Dicrocoeliidae Odhner et sur les parasites des Damans. Revue Suisse de Zoologie 64: 547-575.

BAER, J.G. 1971. Trématodes de rongeurs récoltés en Côte d'Ivoire. Parasitology Research 37: 226-254.

CANARIS, A.G. \& GARDNER, S.L. 2003. Bibliography of helminth species described from African vertebrates 1800-1967. The Harold W. Manter Laboratory of Parasitology, Lincoln.

GARDNER, S.L. \& PÉREZ-PONCE DE LÉON, G. 2002. Yungasicola travassosi gen. n., sp. n. (Digenea: Dicrocoeliidae: Eurytrematinae) from two species of grass mice of the genus Akodon Meyen (Rodentia: Muridae) from the Yungas of Bolivia. Comparative Parasitology 69:51-57.

GIBBONS, L.M., APPLEBY, E.C. \& HOWELL, K.M. 1990. Cyathospirura seurati Gibbs, 1957 (Nematoda, Spiruroidea) from Cricetomys gambianus in Tanzania. Journal of African Zoology 104: 335-344.

GUINDON, S. \& GASCUEL, O. 2003. A simple, fast and accurate method to estimate large phylogenies by 'maximum-likelihood'. Systematic Biology 52: 696-704.

GUINDON S., DUFAYARD, J.F., LEFORT V., ANISIMOVA, M., HORDIJK, W. \& GASCUEL, O. 2010. New algorithms and methods to estimate Maximum-Likelihood phylogenies: assessing the performance of PhyML 3.0. Systematic Biology 59: 307-321.

HILDEBRAND, J., OKULEWICZ, J. \& POPIOLEK, M. 2007. A new dicrocoeliid from the bank vole Clethrionomys glareolus (Rodentia: Microtidae) from Poland. Journal of Parasitology 93: 151-154. 
KHALIL, L.F. 1973. Characostomum howelli n.sp. (Nematoda: Strongylidae) from the giant African rat Cricetomys gambianus and other helminths from Tanzania. Journal of Helminthology 47: 283-287.

LAMOTHE-ARGUMEDO, R., FALCÓN-ORDAZ, J, GARCÍA-PRIETO, L \& FERNÁNDEZ-FERNÁNDEZ J. 2005. A new dicrocoeliid (Digenea: Dicrocoeliinae) parasite of rodents from Tlaxcala, Mexico. Journal of Parasitology 91: 1410-1412.

LITTLEWOOD, D.T.J. \& OLSON, P.D. 2001. SSU rDNA and the Platyhelminthes: signal, noise, conflict and compromise. In: Interrelationships of the Platyhelminthes, (eds) D.T.J. Littlewood \& R.A. Bray, pp. 262-278. Taylor \& Francis, London.

MONTGELARD, C., BENTZ, S., TIRARD, S.C., VERNEAU, O. \& CATZEFILS, F.M. 2002. Molecular systematics of Sciurognathi (Rodentia): the mitochondrial cytochrome $b$ and $12 S$ rRNA genes support the Anomaluroidea (Pedetidae and Anomaluridae). Molecular Phylogenetics and Evolution 22: 220-233.

OGUGE, N., RARIEYA, M., \& ONDIAKA P. 1997. A preliminary survey of macroparasites communities of rodents of Kahawa, central Kenya. Belgian Journal of Zoology 127: 113-118.

OTRANTO, D., REHBEIN, S., WEIGL, S., CANTACESSI, C., PARISI, A., LIA, R.P. \& OLSON, P.D. 2007. Morphological and molecular differentiation between Dicrocoelium dendriticum (Rudolphi, 1819) and Dicrocoelium chinensis (Sudarikov and Ryjikov, 1951) Tang and Tang, 1978 (Platyhelminthes: Digenea) Acta Tropica 104: 91-98.

POJMAŚKA, T. 2008. Family Dicrocoeliidae Loos, 1899. In: Keys to the Trematoda. Volume 3, (eds) R.A. Bray, D.I. Gibson \& A. Jones, pp. 233-260. CABI Publishing, Wallingford.

POSADA, D. 2008. jModelTest: phylogenetic model averaging. Molecular Biology and Evolution 25: 1253 1256.

QUENTIN, J.C. 1989. Prévalence des helminthes de rongeurs myomorphes d'Afrique Centrale. Relations entre l'écologie et l'éthologie de ces rongeurs et leurs peuplements parasitaires. Bulletin Ecologie 20: 311-323.
RIVILLAS, C., CARO, F., CARVAJAL, H. \& VÉLEZ, I. 2004. Conspicuum thatcheri sp. nov. (Trematoda: Dicrocoeliidae) de Orysomys caliginosus (Rodentia, Mammalia) del Departamento de Valle, Colombia. Revista Academia Colombiana Ciencias Exactas, Físicas y Naturales 28: 275-279.

SCHLITTER, D. \& VAN DER STRAETEN, E. 2008. Hylomyscus stella. In: IUCN 2011. IUCN Red List of threatened species. Version 2011.2. Online at: www.iucnredlist.org (accessed 28 December 2011).

SENZOTA, R.B.M., SABUNI, C. \& MSUHA, M. 2012. A checklist of Tanzanian mammals. In: Checklist of Tanzanian Species (version 1, 2012), (eds) H. Gideon, P. Nyinyondi \& G. Oyema, pp. 221-238. Tanzania Commission for Science and Technology, Dar es Salaam, Tanzania.

TAMURA, K., PETERSON, D., PETERSON, N., STECHER, G., NEI, M. \& KUMAR, S. 2011. MEGA5: Molecular evolutionary genetics analysis using maximum likelihood, evolutionary distance, and maximum parsimony methods. Molecular Biology and Evolution 28: 2731-2739.

THOMPSON, J.D., HIGGINS, D.G. \& GIBSON. T.J. 1994. CLUSTAL W: improving the sensitivity of progressive multiple sequence alignment through sequence weighting, position-specific gap penalties and weight matrix choice. Nucleic Acids Research. 22: 4673-4680.

VASSILIADĖS. \& RICHARD G.J. 1970. Paraconcinnum hylomisci n.gen., n.sp. (Trematoda: Dicrocoeliidae), parasite of Hylomiscus stella Peters (Muridae). Bulletin du Muséum National d'Histoire Naturelle 41: 1261-1265.

VERHEYEN, W., HULSELMANS, J., WENDELEN, W., LEIRS, H., CORTI, M., BACKELJAU, T. \& VERHEYEN, E. 2011. Contribution to the systematics and zoogeography of the East-African Acomys spinosissimus Peters 1852 species complex and the description of two new species (Rodentia: Muridae). Zootaxa 3059: 1-35.

ZHENG, Y., LUO, X., JING, Z., HU, Z. \& CAI, X. 2007. Comparison of $18 \mathrm{~S}$ ribosomal RNA gene sequences of Eurytrema coelmaticum and Eurytrema pancreaticum. Parasitology Research 100: 645-646.

Responsible Editor: P.J. Taylor 